УДК 616-001.4-085.33:615.03.032:612-092.9

DOI 10.11603/mcch.2410-681X.2019.v.i2.10293

І. Я. Дзюбановський ${ }^{1}$, Б. М. Вервега ${ }^{2}$, С. Р. Підручна ${ }^{1}$, Н. А. Мельник ${ }^{1}$, А. А. Гудима ${ }^{1}$ ТЕРНОПІЛЬСЬКИЙ ДЕРЖАВНИЙ МЕДИЧНИЙ УНІВЕРСИТЕТ IMЕНІ І. Я. ГОРБАЧЕВСЬКОГО ЛЬВІВСЬКИЙ НАЦІОНАЛЬНИЙ МЕДИЧНИЙ УНІВЕРСИТЕТ ІМЕНІ ДАНИЛА ГАЛИЦЬКОГО

\title{
ДИНАМІКА ПОКАЗНИКІВ ОКИСНЮВАЛЬНОЇ МОДИФІКАЦІЇ БІЛКІВ ЗА УМОВ ЕКСПЕРИМЕНТАЛЬНОГО ПЕРИТОНІТУ НА ТЛІ ЦУКРОВОГО ДІАБЕТУ
}

Вступ. Накопичення окиснених білків розглядають як один із фракторів регуляції синтезу і розпаду білків, активації мультикаталітичних протеаз, які вибірково руйнують окиснені білки. Відомо, що цукровий діабет супроводжується порушенням усіх видів обміну речовин, тому доцільним було вивчення особливостей однієї з патогенетичних ланок гострого поширеного перитоніту, який виник на тлі цукрового діабету, - окиснювальної модифрікації білків.

Мета дослідження - вивчити та оцінити стан окиснювальної модифрікації білків в організмі піддослідних тварин при змодельованому гострому поширеному перитоніті на тлі цукрового діабету порівняно зі щурами з експериментальним гострим поширеним перитонітом.

Методи дослідження. У роботі використано 56 білих щурів. Цукровий діабет моделювали шляхом внутрішньочеревного введення стрептозотоцину фрірми “Sigmal” з розрахунку 7 мг на 100 г маси щура, гострий поширений перитоніт - введення 0,5 мл 10 \% проорільтрованої калової суспензії в черевну порожнину піддослідних тварин. Визначали показники окиснювальної модифрікації білків - концентрацію альдегідо- та кетопохідних нейтрального (ОМБ $\left.{ }_{370}\right)$ й основного $\left(О \mathrm{MБ}_{43}\right)$ характеру. Терміни спостереження - 1-ша, 3-тя, 7-ма доби від початку моделювання перитоніту. Для проведення досліджень використовували сироватку крові.

Результати й обговорення. При порівнянні показників окиснювальної модифрікації білків між досліджуваними групами тварин було встановлено статистично значиме більш вагоме зростання рівня середньомолекулярних пептидів протягом усіх термінів експерименту. Зокрема, концентрація ОМБ Зто $_{\text {ma ОМБ }}$ у тварин основної групи на 1-шу добу з моменту початку експерименту була на 35,56 і 84,94 \% вищою стосовно таких показників у щурів із гострим перитонітом ( $>>0,05)$. На 3-тю добу ця різниця становила 30,51 та 42,85 \%, а на 7-му - 26,49 і 21,02 \% відповідно ( $p<0,05)$. Це свідчить про підсилення токсичного впливу гострого поширеного перитоніту на тлі цукрового діабету в організмі піддослідних тварин.

Висновки. У тварин із гострим поширеним перитонітом спостерігають виражену активацію процесів вільнорадикального окиснення білків, що проявляється достовірним зростанням показників окиснювальної модифрікації. Інтенсивність окиснювальної модифрікації білків за умов комбінованої патології переважає інтенсивність стосовно ізольованої, що свідчить про потенціювання прооксидантної дії продуктів метаболізму при цукровому діабеті, й ускладнює перебіг гострого поширеного перитоніту. білків.

КЛЮЧОВІ СЛОВА: гострий поширений перитоніт; цукровий діабет; окиснювальна модифрікація

ВСТУП. Вважають, що в основі поліорганної недостатності при гострому поширеному перитоніті (ГПП) на тлі цукрового діабету (ЦД) лежать єдині універсальні механізми. Ключовою ланкою, що запускає процеси розвитку ендотоксикозу, є гіперметаболізм, який виникає у відповідь на системне ушкодження незалежно від етіологічного орактора [1-3]. Дискоординація окиснювальних процесів відіграє важливу роль у патогенезі багатьох патологічних порушень, зумовлених (c) І. Я. Дзюбановський, Б. М. Вервега, С. Р. Підручна Н. А. Мельник, А. А. Гудима, 2019. впливом на організм токсичних продуктів, утворених при посиленому катаболізмі, й може бути причиною токсичної загибелі клітини [4]. Наслідком посилення пероксидного окиснення ліпідів (ПОЛ) є мембранотоксичний ефект, що призводить до дезінтеграції клітин, як ліпідних, так і білкових її компонентів.

Роль пероксидного окиснення ліпідів у діяльності клітин за умов фрізіологічної норми та патогенезі ряду патологічних процесів достатньо вивчено і відображено в публікаціях вітчизняних та зарубіжних дослідників $[5,6]$. Що ж стосуєть- 
ся окиснювальної модифрікації білків (ОМБ), то можна констатувати, що дослідження цього процесу перебувають на початковому етапі й детальні його механізми та шляхи регуляції потребують подальшого вивчення.

Процеси окиснювальної модифрікації білків перебігають не лише за умов патології, але й при нормальному функціонуванні організму. Накопичення окиснених білків розглядають як один із фракторів регуляції синтезу і розпаду білків, активації мультикаталітичних протеаз, які вибірково руйнують окиснені білки. Вважають, що окиснення фрерментів $€$ маркером обороту білків.

Цукровий діабет супроводжується порушенням усіх видів обміну речовин, виснаженням системи антиоксидантного захисту, тому доцільним було вивчення особливостей однієї з патогенетичних ланок ГПП, який виник на тлі ЦД, окиснювальної модифрікації білків. Таким чином, у процесі розвитку патологічних станів організму важливу роль відіграє пероксидація не лише ліпідів, але й білків, що потребує подальших досліджень у цьому напрямку. Вивченню ролі окиснення білків за умов патології присвячено ряд наукових публікацій. Однак даних про роль ОМБ при ГПП на тлі ЦД у доступній нам літературі ми не зустрічали.

Мета дослідження - вивчити та оцінити стан окиснювальної модифрікації білків в організмі піддослідних тварин при змодельованому гострому поширеному перитоніті на тлі цукрового діабету порівняно зі щурами з експериментальним гострим поширеним перитонітом.

МЕТОДИ ДОСЛІДЖЕННЯ. Експерименти виконано на базі Центральної науково-дослідної лабораторії Тернопільського державного медичного університету імені І. Я. Горбачевського.

У роботі використано 56 білих щурів, яких було поділено на 3 групи: основну - 24 тварини зі змодельованим ГПП на тлі ЦД; групу порівняння - 24 тварини зі змодельованим перитонітом; контрольну - 8 інтактних тварин, яких утримували у стандартних умовах віварію. Усі порівнювані групи тварин були репрезентативними за масою, статтю і віком.

Експериментальний ЦД відтворювали шляхом внутрішньочеревного введення натщесерце стрептозотоцину (фірми "Sigmal") в дозі 60 мг/кг, який розчиняли в бусрерному натрієво-цитратному розчині (рН 4,5). Вміст глюкози досліджували глюкозооксидантним методом о 9:00 за умов вільного доступу експериментальних тварин до їжі та води протягом нічного періоду часу. Впродовж усього спостереження щурам вводили інсулін (0-2 ОД підшкірно 2-5 разів на тиждень) [7].
Через 2 тижні з моменту застосування стрептозотоцину у венозній крові щурів, яку отримували із хвостової вени, визначали вміст глюкози, і в подальших дослідженнях використовували тільки тих тварин, у яких він становив понад 300 мг/л. Тваринам контрольної групи замість стрептозотоцину вводили підшкірно стерильний 0,9 \% розчин натрію хлориду [8].

Вплив ЦД на перебіг ГПП вивчали на моделі, запропонованій В. А. Лазаренком і співавт. [9]. Ця модель за етіологічними чинниками, клінічними проявами і фразністю перебігу близька до аналогічного процесу в людини. На 14-ту добу після введення стрептозотоцину тваринам основної групи вводили 10 \% профрільтровану калову суспензію в черевну порожнину досліджуваних щурів у дозі 0,5 мл на 100 г маси тіла. Щурам групи порівняння лише підшкірно вводили калову суспензію. Калову суспензію отримували шляхом змішування ізотонічного розчину і калу зі сліпої кишки 2-3 інтактних тварин, потім ії двічі фрільтрували через подвійний шар марлі. Одержану суспензію не пізніше ніж через 20 хв після приготування вводили інтактним щурам пункційним способом. Щоб уникнути ушкодження внутрішніх органів при введенні калової суспензії в черевну порожнину, тварин тримали вертикально, каудальним кінцем вгору. Методом пункції вентральної стінки в центрі середньої лінії живота, направляючи кінець голки по черзі у праве і ліве підребер'я, праву та ліву клубові ділянки, вводили однакову кількість калової суспензії.

Терміни спостереження - 1-ша, 3-тя і 7-ма доби від початку моделювання перитоніту. Для проведення досліджень використовували цільну кров та сироватку крові.

Дані експериментальні дослідження проводили 3 дотриманням загальних правил і положень Європейської конвенції про захист хребетних тварин, що використовуються для дослідних та інших наукових цілей (Страсбург, 1986), Загальних етичних принципів експериментів на тваринах (Київ, 2001) та Закону України "Про захист тварин від жорстокого поводження" (2006).

Рівень пероксидного окиснення білків встановлювали у всіх досліджуваних тканинах за кількістю продуктів їх окиснювальних модисрікацій за допомогою спектрофротометрії при довжині хвилі 370 і 430 нм [10]. Методика ґрунтується на реакції взаємодії окиснених амінокислотних залишків білків із 2,4-динітрофенілгідразином 3 утворенням похідних 2,4-динітрофренілгідразону, оптичну щільність яких визначали спектрофротометрично. Відомо, що в результаті окиснення білків, залежно від переважання в їх молекулах 
амінокислот нейтрального (валін, лейцин, ізолейцин та ін.) або основного (лізин, аргінін тощо) характеру, утворюються альдегідо- чи кетопохідні нейтрального або основного характеру, які мають різні діапазони спектра поглинання. При довжині хвилі 370 нм визначають кетодинітрофренілгідразони нейтрального характеру, при довжині хвилі 430 нм реєструють, відповідно, альдегідодинітрофренілгідразони основного характеру.

Статистичну обробку цифррових даних здійснювали за допомогою програмного забезпечення Excel i STATISTICA з використанням параметричних методів оцінки отриманих даних. Для всіх показників розраховували значення середньої ариорметичної вибірки (М), її дисперсії і помилки середньої (m). Достовірність різниці значень між незалежними кількісними величинами визначали при нормальному розподілі за t-критерієм Стьюдента (достовірними вважали відмінності при $р<0,05)$.

РЕЗУЛЬТАТИ Й ОБГОВОРЕННЯ. ПрИ ДОСЛідженні ОМБ у щурів з експериментальним ГПП на 1-шу добу від початку моделювання (табл. 1) зареєстровано збільшення вмісту ОМБ ${ }_{370}$ і $\mathrm{OMБ}_{430}$ у плазмі крові - в 1,27 та 1,67 раза відповідно порівняно з інтактними тваринами. На 3-тю добу експерименту вміст ОМБ також зростав, що вказувало на збільшення інтенсивності катаболічних процесів. Найвищого рівня вміст

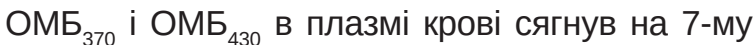
добу від моменту ураження, що становило, відповідно, 2,13 та 3,65 раза стововно норми $(p<0,05)$. Зростання вмісту ОМБ в організмі тварин після моделювання ГПП свідчило про посилення катаболічних процесів. Зважаючи на те, що вміст ОМБ залежить від співвідношення між швидкістю деградації з участю внутрішньоклітинних протеаз, а також співвідношення між активними формами кисню та антиоксидантною системою організму, підвищення активності альдегідо- і кетопохідних нейтрального та основного характеру в уражених тварин може бути зумовлене як зниженням активності специфічних протеаз, так і недостатністю антиоксидантної системи.

Так чи інакше, але вміст ОМБ, як і продуктів поЛ, призводить до посилення ендогенного токсикозу, що підтвержують наведені вище маркери ендогенної інтоксикації.

При дослідженні ОМБ у щурів, яким було змодельовано ГПП на тлі ЦД, виявлено лінійне зростання їх концентрації протягом усіх днів експерименту (табл. 2). Максимальну величину вмісту альдегідо- та кетопохідних нейтрального й основного характеру в плазмі крові піддослідних тварин спостерігали на 7-му добу з моменту початку експерименту, і вона становила стосовно норми, відповідно, 2,69 раза $\left(\mathrm{OMБ}_{370}\right)$ і 4,42 раза $\left(\mathrm{OMБ}_{430}\right)$. Ці показники були достовірно

Таблиця 1 - Концентрація альдегідо- та кетопохідних нейтрального (ОМБ $\left.{ }_{370}\right)$ й основного (ОМБ $\left.{ }_{430}\right)$ характеру в крові щурів із гострим поширеним перитонітом (ммоль/г білка)

\begin{tabular}{|c|c|c|c|c|}
\hline \multirow{3}{*}{ Показник } & \multicolumn{4}{|c|}{ Група піддослідних тварин } \\
\hline & \multirow{2}{*}{$\begin{array}{c}\text { інтактні } \\
(\mathrm{n}=8)\end{array}$} & \multicolumn{3}{|c|}{ тварини з ГПП $(\mathrm{n}=24)$} \\
\hline & & 1-ша доба $(n=8)$ & 3-тя доба $(n=8)$ & 7-ма доба $(n=8)$ \\
\hline $\mathrm{OMB}_{370}$ & $0,71 \pm 0,02$ & $0,90 \pm 0,04^{\#}$ & $1,18 \pm 0,05^{\#}$ & $1,51 \pm 0,02^{\#}$ \\
\hline $\mathrm{OMB}_{430}$ & $0,43 \pm 0,05$ & $0,72 \pm 0,03^{\#}$ & $1,12 \pm 0,05^{\#}$ & $1,57 \pm 0,02^{\#}$ \\
\hline
\end{tabular}

Примітка. \# - достовірність різниці стосовно таких показників групи інтактних тварин.

Таблиця 2 - Концентрація альдегідо- та кетопохідних нейтрального (ОМБ ${ }_{370}$ ) й основного (ОМБ $\left.{ }_{430}\right)$ характеру в крові щурів із гострим поширеним перитонітом на тлі цукрового діабету (ммоль/г білка)

\begin{tabular}{|c|c|c|c|c|}
\hline \multirow{3}{*}{ Показник } & \multicolumn{4}{|c|}{ Група піддослідних тварин } \\
\hline & \multirow{2}{*}{$\begin{array}{c}\text { інтактні } \\
(\mathrm{n}=8)\end{array}$} & \multicolumn{3}{|c|}{ тварини з ГПП на тлі ЦД (n=24) } \\
\hline & & 1-ша доба $(n=8)$ & 3-тя доба $(\mathrm{n}=8)$ & 7-ма доба $(n=8)$ \\
\hline $\mathrm{OME}_{370}$ & $0,71 \pm 0,02$ & $\begin{array}{c}1,22 \pm 0,03^{\#} \\
{ }^{*} \mathrm{p}<0,05\end{array}$ & $\begin{array}{c}1,54 \pm 0,03^{\#} \\
{ }^{*} p<0,05 \\
{ }^{\#} p<0,05\end{array}$ & $\begin{array}{c}1,91 \pm 0,04^{\#} \\
{ }^{*} p<0,05 \\
{ }^{\#} p<0,05 \\
* \star p<0,05\end{array}$ \\
\hline $\mathrm{OMF}_{430}$ & $0,43 \pm 0,05$ & $\begin{array}{c}1,31 \pm 0,02^{*} \\
{ }^{*} p<0,05\end{array}$ & $\begin{array}{c}1,60 \pm 0,04^{\#} \\
{ }^{*} p<0,05 \\
{ }^{\#} p<0,05\end{array}$ & $\begin{array}{c}1,90 \pm 0,03^{\#} \\
{ }^{*} p<0,05 \\
{ }^{\#} p<0,05 \\
* * p<0,05\end{array}$ \\
\hline
\end{tabular}

Примітки:

1. \# - достовірність різниці стосовно таких показників групи інтактних тварин.

2. * - достовірність різниці стосовно таких показників групи порівняння.

3. - достовірність різниці стосовно таких показників групи тварин на 1-шу добу спостереження.

4. ** - достовірність різниці стосовно таких показників групи тварин на 3-тю добу спостереження. 
вищими, ніж ті, які ми отримали за умов роздільного введення кожного з досліджуваних токсикантів.

При порівнянні рівня ОМБ між досліджуваними групами тварин було встановлено статистично значиме більш вагоме зростання рівня альдегідо- та кетопохідних нейтрального й основного характеру протягом усіх термінів експерименту. Зокрема, концентрація ОМБ ${ }_{370}$ та $\mathrm{OMБ}_{430}$ на 1-шу добу з моменту початку експерименту була на 35,56 і 84,94 \% відповідно вищою у групі ГПП+ЦД стосовно групи щурів із змодельованим ГПП. На 3-тю добу відмічали аналогічну тенденцію: концентрація ОМБ ${ }_{370}$ у тварин із поєднаною патологією була на 30,51 \% більшою порівняно зі щурами з ізольованою патологією, а концентрація ОМБ ${ }_{430}-$ на 42,85 \% $(p<0,05)$. На 7-му добу експерименту різниця між рівнями ОМБ ${ }_{370}$ та ОМБ пах становила 26,49 і 21,02 \% відповідно $(p<0,05)$. Це свідчило про підсилення процесів
ОМБ при ГПП за умов комбінованої патології, зокрема при ЦД, в організмі піддослідних тварин.

ВИСНОВКИ. 1. У тварин із гострим поширеним перитонітом спостерігають виражену активацію процесів вільнорадикального окиснення білків, що проявляється достовірним зростанням показників окиснювальної модифрікації.

2. Інтенсивність окиснювальної модисрікації білків за умов комбінованої патології переважає інтенсивність стосовно ізольованої, що свідчить про потенціювання прооксидантної дії продуктів метаболізму при цукровому діабеті, й ускладнює перебіг гострого поширеного перитоніту.

Перспективи подальших досліджень. Заплановано дослідити взаємозалежність між процесами окиснювальної модифрікації білків та антиоксидантним захистом у тварин із змодельованим гострим поширеним перитонітом на тлі цукрового діабету.

\section{СПИСОК ЛІТЕРАТУРИ}

1. Дзюбановський І. Я. Синдром поліорганної недостатності та його корекція у хворих на гострий поширений перитоніт / І. Я. Дзюбановський, Б. О. Мігенько // Укр. Журн. Хірургії. - 2009. - № 2. - С. 56-59.

2. Білик І. І. Гострий перитоніт як ускладнення гострого апендициту / І. І. Білик // Клініч. та експерим. патологія. - 2016. - № 1 (43). - С. 187-189.

3. Гринчук Ф.В.Патогенетичні, клінічні і тактичні особливості при перитоніті та поєднаній патології / Ф. В. Гринчук // Харк. Хірург. шк. - 2014. - № 6 (44). C. 47-49.

4. Spirt M. J. Complicated intra-abdominal infections: a focus on appendicitis and diverticulitis / M. J. Spirt // Postgrad. Med. - 2010. - 122, No. 1. - P. 39-51.

5. Kimura W. Problems and therapeutic strategy for emergen cy operation of the abdomen in the aged / W. Kimura, M. Mizutani, A. Fuse // Nippon Ronen Igakkai Zasshi. - 2014. - 41, No. 6. - P. 660-665.

6. Rodney Levine L. Oxidative modification of proteins during aging / Rodney L. Levine, Earl R. Stadt- man // Experimental Gerontology. - 2001. - 36 (9). P. 1495-1502. -Access mode : http://dx.doi.org/10.1016/ S0531-5565(01)00135-8.

7. Стефранов О. В. Доклінічні дослідження лікарських засобів / О. В. Стесранов. - К. : Авіцена, 2001. $568 \mathrm{c}$.

8. Al-Malki A. L. (2013). Oat attenuation of hyperglycemia-induced retinal oxidative stress and NF-kkB activation in streptozotocin-induced diabetic rats / A. L. AlMalki. - Hindawi Publishing Corporation Evidence-Based Complementary and Alternative Medicine Volume.

9. Экспериментальная модель распространенного калового перитонита / В. А. Лазаренко, В. Ф. Липатов, Ю. Ю. Блинков, Д. В. Скориков // Человек и его здоровье. - 2008. - 4. - С. 128-132.

10. Семенюк Г. Д. Стан інтенсивності окиснювальної модифрікації білків та активності антиоксидантних орерментів у ротовій рідині хворих на генералізований пародонтит / Г. Д. Семенюк, Г.М.Мельничук, Г.М.Ерстенюк // Арх. клініч. медицини. - 2013. - № 2 (19). C. 69-71.

\section{REFERENCES}

1. Dziubanovskyi, I.Ya., \& Mihenko, B.O. (2009). Syndrom poliorhannoi nedostatnosti ta yoho korektsiia u khvorykh na hostryi poshyrenyi perytonit [Multiple organ failure syndrome and its correction in patients with acute peritonitis]. Ukr. zhurn. Khirurhii - Ukrainian Journal of Surgery, 2, 56-59 [in Ukrainian].
2. Bilyk, I.I. (2016). Hostryi perytonit yak uskladnennia hostroho apendytsytu [Acute peritonitis as a complication of acute appendicitis]. Klinichna ta eksperymentalna patolohiia - Clinical and Experimental Pathology, 1 (43), 187-189 [in Ukrainian]. 
3. Hrynchuk, F.V. (2014). Patohenetychni, klinichni i taktychni osoblyvosti pry perytoniti ta poiednanii patolohii [Pathogenetic, clinical and tactical features in peritonitis and combined pathology]. Kharkivska khirurhichna shkola - Kharkiv Surgical School, 6 (44), 47-49 [in Ukrainian].

4. Spirt, M.J. (2010). Complicated intra-abdominal infections: a focus on appendicitis and diverticulitis. Postgrad. Med., 122, 1, 39-51.

5. Kimura, W., Mizutani, M., \& Fuse, A. (2014). Problems and therapeutic strategy for emergency operation of the abdomen in the aged. Nippon Ronen Igakkai Zasshi, 41, 6, 660-665.

6. Rodney Levine Levine, \& Earl R. Stadtman (2001). Oxidative modification of proteins during aging. Experimental Gerontology, 36, (9), 1495-1502. http://dx.doi. org/10.1016/S0531-5565(01)00135-8.

7. Stefanov, O.V. (2001). Doklinichni doslidzhennia likarskykh zasobiv [Pre-clinical examination of medical drigs]. Kyiv: "Avitsena" [in Ukrainian].
8. Al-Malki, A.L. (2013). Oat attenuation of hyperglycemia-induced retinal oxidative stress and NF-kkB activation in streptozotocin-induced diabetic rats. Hindawi Publishing Corporation Evidence-Based Complementary and Alternative Medicine Volume.

9. Lazarenko, V.A., Lypatov, V.A., Blynkov, Yu.Yu., \& Skorykov, D.V. (2008). Eksperymentalnaya model rasprostranennogo kalovogo peritonita [Experimental model of diffuse fecal peritonitis]. Chelovek i eho zdorovye - Man and His Health, 4, 128-132 [in Russian].

10. Semeniuk, H.D., Melnychuk, H.M., \& Ersteniuk, H.M. (2013). Stan intensyvnosti okysniuvalnoi modyfikatsii bilkiv ta aktyvnosti antyoksydantnykh fermentiv u rotovii ridyni khvorykh na heneralizovanyi parodontyt [State of intensity of oxidative modification of proteins and activity of antioxidant enzymes in the oral liquid of patients with generalized periodontitis]. Arkh. klinich. medytsyny - Archieve of Clinical Medicine, 2, (19), 69-71 [in Ukrainian].

И. Я. Дзюбановский ${ }^{1}$, Б. М. Вервега ${ }^{2}$, С. Р. Пидручная ${ }^{1}$, Н. А. Мельник ${ }^{1}$, А. А. Гудыма ${ }^{1}$ ТЕРНОПОЛЬСКИЙ ГОСУДАРСТВЕННЫЙ МЕДИЦИНСКИЙ УНИВЕРСИТЕТ ИМЕНИ И. Я. ГОРБАЧЕВСКОГО ЛЬВОСКИЙ НАЦИОНАЛЬНЫЙ МЕДИЦИНСКИЙ УНИВЕРСИТЕТ ИМЕНИ ДАНИЛА ГАЛИЦКОГО

\section{ДИНАМИКА ПОКАЗАТЕЛЕЙ ОКИСЛИТЕЛЬНОЙ МОДИФИКАЦИИ БЕЛКОВ ПРИ ЭКСПЕРИМЕНТАЛЬНОМ ПЕРИТОНИТЕ НА ФОНЕ САХАРНОГО ДИАБЕТА}

\section{Резюме}

Вступление. Накопление окисленных белков рассматривают как один из фракторов регуляции синтеза и распада белков, активации мультикаталитических протеаз, которые избирательно разрушают окисленные белки. Известно, что сахарный диабет сопровождается нарушением всех видов обмена веществ, поэтому челесообразным было изучение особенностей одного из патогенетических звеньев острого распространенного перитонита, возникшего на фроне сахарного диабета, - окислительной модифрикации белков.

Цель исследования - изучить и оценить состояние окислительной модификации белков в организме подопытных животных при смоделированном остром распространенном перитоните на фроне сахарного диабета по сравнению с крысами с экспериментальным острым распространенным перитонитом.

Методы исследования. В работе использовано 56 белых крыс. Сахарный диабет моделировали путем внутрибрюшного введения стрептозотоцина фрирмы "Sigmal" из расчета 7 мг на 100 г массы крысы, острый распространенный перитонит - введения 0,5 мл $10 \%$ профильтрованной каловой суспензии в брюшную полость подопытных животных. Определяли показатели окислительной модификации белков - концентрацию альдегидо- и кетопроизводных нейтрального (ОМБ $\left.{ }_{370}\right)$ и основного (ОМБ $\left.{ }_{43}\right)$ характера. Сроки наблюдения - первые, третьи, седьмые сутки от начала моделирования перитонита. Для проведения исследований использовали сыворотку крови.

Результаты и обсуждение. При сравнении показателей окислительной модификации белков между исследуемыми группами животных было установлено статистически значимое более существенное возрастание уровня среднемолекулярных пептидов в течение всех сроков эксперимента. В частности, концентрация ОМБ ${ }_{370}$ и ОМБ ${ }_{430}$ у животных основной группы на первые сутки с момента начала эксперимента была на 35,56 и 84,94\% выше относительно таких показателей у крыс с острым перитонитом (р>0,05). На третьи сутки эта разница составляла 30,51 и 42,85 \%, а на седьмые - 26,49 и 21,02 \% соответственно (p<0,05). Это свидетельствует об усилении токсического воздействия острого распространенного перитонита на фроне сахарного диабета в организме подопытных животных.

Выводы. У животных с острым распространенным перитонитом наблюдают выраженную активацию процессов свободнорадикального окисления белков, что проявляется достоверным ростом показателей окислительной модификации. Интенсивность окислительной модификации белков в условиях 
комбинированной патологии преобладает интенсивность относительно изолированной, что свидетельствует о потенцировании прооксидантного действия продуктов метаболизма при сахарном диабете, и осложняет течение острого распространенного перитонита.

КЛЮЧЕВЫЕ СЛОВА: острыЙ распространенный перитонит; сахарный диабет; окислительная модификация белков.

I. Ya. Dziubanovskyi ${ }^{1}$, B. M. Verveha' ${ }^{2}$ S. R. Pidruchna ${ }^{1}$, N. A. Melnyk ${ }^{1}$, A. A. Hudyma ${ }^{1}$ I. HORBACHEVSKY TERNOPIL STATE MEDICAL UNIVERSITY ${ }^{1}$ DANYLO HALYTSKYI LVIV NATIONAL MEDICAL UNIVERSITY²

\title{
DYNAMICS OF INDICATORS OF OXIDATIVE MODIFICATION OF PROTEINS UNDER THE EXPERIMENTAL PERITONITIS AGAINST DIABETES MELLITUS
}

\begin{abstract}
Summary
Introduction. The accumulation of oxidized proteins is considered as one of the factors regulating the synthesis and degradation of proteins, the activation of multicatalytic proteases, which selectively destroy oxidized proteins. It is known that diabetes mellitus is accompanied by a violation of all types of metabolism, so it is expedient to study the features of one of the pathogenetic links of acute diffuse peritonitis, which arose on the background of diabetes mellitus - an oxidation modification of proteins.

The aim of the study - to investigate and assess the state of the oxidative modification of proteins in the body of experimental animals in the simulated acute prevalent peritonitis on the background of diabetes mellitus compared with animals with experimental acute peritonitis.

Research Methods. 56 white rats were used in this work. Diabetes mellitus was modeled by intraperitoneal injection of streptozotocin of Sigmal brand at a rate of $7 \mathrm{mg}$ per $100 \mathrm{~g}$ of animal weight, acute peritonitis - by administering of $0.5 \mathrm{ml}$ of $10 \%$ filtered fecal suspension to the abdominal cavity of the animals under study. The indexes of oxidative modification of proteins were determined - concentration of aldehyde and keto-derivative neutral $\left(O M P_{370}\right)$ and basic $\left(\mathrm{OMP}_{430}\right)$ character. Terms of observation: 1, 3, 7 days from the beginning of the peritonitis modeling. Blood serum was used for research.

Results and Discussion. When comparing the indices of oxidative modification of proteins between the studied groups of animals, statistically significant increase in the level of medium molecular peptides during all the experimental periods was established. In particular, the concentration of $\mathrm{OMP}_{370}$ and $O M P_{430}$ in animals of the main group for 1 day since the beginning of the experiment was $35.56 \%$ and $84.94 \%$ higher relative to those of the group with acute peritonitis $(p<0.05)$. On the $3 r d$ day this difference was $30.51 \%$ and $42.85 \%$, while on the 7 th day it was $26.49 \%$ and $21.02 \%$, respectively $(p<0.05)$. This confirms the strengthening of the toxic effects of acute common peritonitis on the background of diabetes mellitus in the test animals.

Conclusions. In animals with acute widespread peritonitis, pronounced activation of free radical oxidation of proteins is observed, which is manifested by a significant increase in the parameters of oxidative modification. The intensity of the oxidative modification of proteins in conditions of combined pathology is prevalent in intensity relative to isolated, indicating the potentiation of the prooxidant action of metabolic products in diabetes mellitus, and complicates the course of acute common peritonitis.
\end{abstract}

KEY WORDS: acute common peritonitis; diabetes; oxidative modification of proteins.

Адреса для листування: Б. М. Вервега, вул. Соколина, 23, Львів, 79038, Україна, e-mail: danaverveha@gmail.com.. 